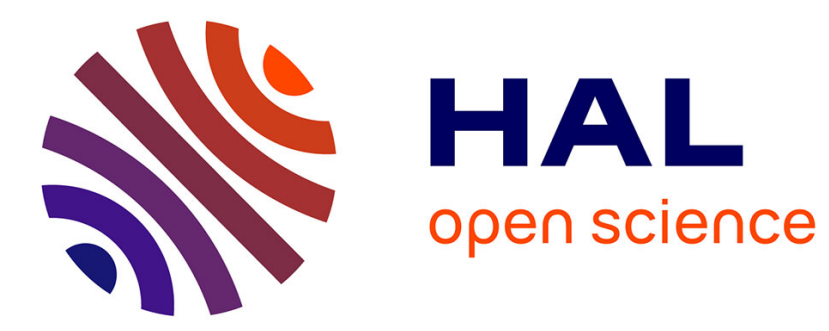

\title{
Reduplication in Tupi-Guarani languages: going into opposite directions \\ F. Rose
}

\section{To cite this version:}

F. Rose. Reduplication in Tupi-Guarani languages: going into opposite directions. Studies on Reduplication, Mouton de Gruyter, pp.351-368, 2005. halshs-00724365

\section{HAL Id: halshs-00724365 \\ https://shs.hal.science/halshs-00724365}

Submitted on 20 Aug 2012

HAL is a multi-disciplinary open access archive for the deposit and dissemination of scientific research documents, whether they are published or not. The documents may come from teaching and research institutions in France or abroad, or from public or private research centers.
L'archive ouverte pluridisciplinaire HAL, est destinée au dépôt et à la diffusion de documents scientifiques de niveau recherche, publiés ou non, émanant des établissements d'enseignement et de recherche français ou étrangers, des laboratoires publics ou privés. 


\title{
Reduplication in Tupi-Guarani languages: going into opposite directions
}

\author{
Françoise Rose ${ }^{1}$
}

The aim of this paper is to investigate verbal stem reduplication in several Tupi-Guarani languages. The study reports mostly on Emerillon, for which the author collected field data in French Guiana, but also on other TupiGuarani languages: Wayampi of French Guiana (Grenand 1980, 1989; Ganozzi, p.c.), Tupinamba (Rodrigues A. 1953), Kamaiura (Seki 2000), Brazilian Wayampi (Jensen 1989), Anambé (Julião, p.c.), Urubu-Kaapor (Kakumasu 1984), Chiriguano (Shuchard 1979) and Guarayo (Hoeller $1932)^{2}$. Tupi-Guarani languages in general display both a monosyllabic and a disyllabic reduplication pattern. However, while in other Tupi-Guarani languages the patterns copy the final syllables of the stem, in Emerillon the reduplication clearly affects the initial syllables. Let us note that up to now, general descriptions of Tupi-Guarani languages rarely included Emerillon data due to insufficient description.

The reduplication process to be studied is a productive morphological process with the verb stem. Reduplication is also used with other parts of speech (like minor predicative categories, nouns or adverbs), but is really productive and frequent with verbs and ideophones only. Verbal reduplication is an expressive means for different nuances of aspect. Aspectual distinctions are otherwise expressed by verbal suffixes and particles in Tupi-Guarani languages.

The first section will present the semantics of the two patterns, the second the phonological description of the reduplication patterns, both for Tupi-Guarani languages in general and for Emerillon in particular. The last one focuses on diachronic information that may explain the specificities of Emerillon as far as reduplication is concerned. 


\section{Semantic analysis}

The semantics of Tupi-Guarani reduplication is totally iconic: it conveys a meaning of multiplicity or repetition.

1.1. Dichotomy between monosyllabic and disyllabic reduplication

Most descriptions of Tupi-Guarani languages present a very neat dichotomy between the semantics of monosyllabic and disyllabic reduplications, i.e. reduplications in which the copy consists of one and two syllables respectively, irrespective of the length of the reduplicated stem (Jensen 1990 and 1998 on Tupi-Guarani, Seki 2000 on Kamaiura, Rodrigues A. 1953 on Tupinamba and Jensen 1989 on Wayampi). Monosyllabic reduplication is generally said to express successive actions and disyllabic reduplication to have a frequentative or iterative meaning.

Spontaneous examples of Emerillon make this semantic distinction stand out. The verbs kusug "wash" and hem "go out" both occur with each type of reduplication, with two different meanings.

a- o-ze-kusug ${ }^{3}$

Emerillon

3-REFL-wash

'She washes (herself).'

$$
\begin{array}{lll}
\text { b- "e- }[k u] \text { kusu(g)-katu } & \text { ay } & \text { bare-kom" } \\
\text { 2SG.IMP-RED-wash-well DEM } & \text { thing-PL } \\
\text { "“Wash these things well.", } &
\end{array}
$$

$$
\begin{array}{ll}
\text { c- o-itun-itun, } & \text { o- }[\mathrm{kusu}] \mathrm{kusu}(\mathrm{g}) \text {-katu-e?e, } \\
\text { 3-RED-smell } & \text { 3-RED-wash-well-INTENS } \\
\text { pug } & \text { o-inu-inun } \\
\text { lay.down } & \text { 3-RED-put }
\end{array}
$$

'He smells them, washes them well and puts them down each time.'

When only one syllable of the verb kusug is reduplicated (1b), the hero of the story is asked to wash a lot of dishes: it expresses successive action on all objects. In the example (1c) with disyllabic reduplication, the same hero does it frequently, every time his master goes away: it expresses iterativity. 


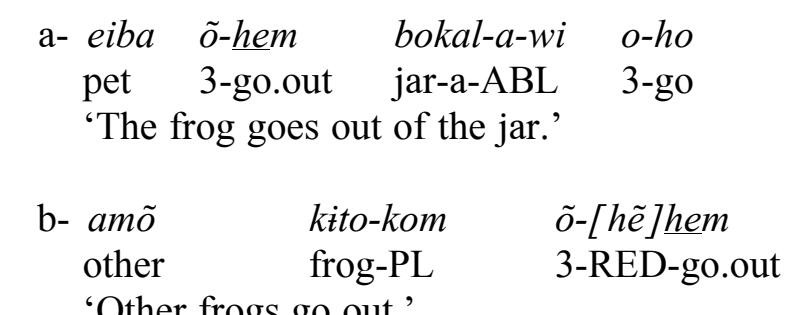

$$
\begin{aligned}
& \text { 'Other frogs go out.' } \\
& \text { c- [õhẽ] } \tilde{\text { o-hem-ne }} \quad o-? a \\
& \text { RED-3-go.out-CONTRAST 3-fall } \\
& \text { 'He goes out again and falls down.' }
\end{aligned}
$$

In (2), whereas the example with monosyllabic reduplication (2b) shows that the different subjects realize the action successively, one frog going out after the other, the disyllabic reduplication (2c) presents a very repetitive action of a single actor, the hero, going in and out the monster's belly.

Additional examples from different languages of the family show that the current definition of these functions in terms of succesivity $V S$ iterativity is too restrictive, since they may vary according to the types of situation denoted by the verbs and according to the types of participants (especially with plural or mass nouns). We will therefore use Cusic's terms "eventinternal" and "event-external plurality" (Cusic 1981). This vocabulary, less simplistic, distinguishes "repetitive" action from "repeated" action. "Repetitive" action must be conceptualized as an "event-internal" verbal plurality, a series of iterated instances: "the units of action are conceived of as confined to a single occasion, and to a single event on that occasion." On the other hand, "repeated" actions must be conceptualized as an "eventexternal" verbal plurality: "the units of action are potentially distributable, though not necessarily distributed, over multiple occasions". This iterative meaning includes habitual and ongoing events.

\subsection{Monosyllabic reduplication expresses event-internal repetition}

Monosyllabic reduplication is presented by Jensen (1989, p. 119) for Ancient Guarani, Kamaiura, Parintintin, Urubu and Wayampi as expressing successive actions: with intransitive verbs, the action is realized by a succession of subjects as in (3), and with transitive verbs, it is realized on a 
succession of objects as in (4). Rodrigues designs it as a "multiple realization of the process, either successive, either simultaneous".

(3) a- oro-pór

1EX-jump

'we jumped'

b- oro-[pó]pór

'we jumped, one after the other'

(4) a- a-i-mokón

1SG-3-swallow

'I swallowed it.'

b- a-i-mo[kó] kón

'I swallowed one after the other.'
Tupinamba, Jensen 1990

my segmentation

Tupinamba, Jensen 1990

my segmentation

Previous examples of Emerillon showed successive repetition with all subjects (2b), and with all objects (1b). But with other verbs, monosyllabic reduplication does rather express internal repetition of the process, without implying the plurality of any participant. In the following example, the process of "gnawing" is necessarily made of several "bitings".

$$
\begin{aligned}
& \text { ãduoba wila o-[su]su?u } \\
& \text { rat wood 3-RED-bite }
\end{aligned}
$$

Emerillon

'The rat gnawed the wood.'

Closely related is the meaning of distribution of the result: in (5) the "gnawed" wood is in several pieces, just as in (6) a canoe is "split at different points".

$$
\begin{array}{ll}
\text { ial } & \text { o-[ze]zeka } \\
\text { canoe } & 3 \text {-RED-break }
\end{array}
$$

Emerillon

'The canoe split at different points'.

These examples illustrate exactly what García-Medall (2003, p. 33) names "disintegration of the object" in his typology of reduplication in Native American languages.

An analysis à la Vendler (1967) shows that verbs usually denoting "achievement", as in (5) and (6), denote "accomplishment" once the reduplication has turned the basic situation into a non punctual process. This matches Grenand's analysis of Wayampi monosyllabic reduplicated forms as expressing "an action that lasts, while repeating" (Grenand 1980, p. 49). 
These last examples outmatch simple successivity, but they all stand in the semantic area of "event-internal" plurality.

\subsection{Disyllabic reduplication expresses event-external repetition}

As for disyllabic reduplication, Jensen $(1989$, p. 120) presents it with a frequentative or iterative meaning. The action may be repeated several times, or in several places.

$$
\begin{aligned}
& \text { a- oro-pór } \\
& \text { 1EX-jump } \\
& \text { 'we jumped' } \\
& \text { b- o[ropó]ro-pór } \\
& \text { 'we jumped frequently' }
\end{aligned}
$$

\section{b- o[ropó]ro-pór}

Tupinamba, Jensen 1990

my segmentation

(8) a- a-i-mokón

1SG-3-swallow

Tupinamba, Jensen 1990

'I swallowed it.'

my segmentation

\section{b- a-i-[mokó]mokón}

'I swallowed them frequently.'

Examples (1c) and (2c) of Emerillon also showed this meaning of iterativity. In those sentences, the verb (normally denoting an accomplishment or an achievement) expresses, in its reduplicated form, an activity that lasts a certain time without any modification.

Chiriguano examples given by Schuchard (1979) suggest that the disyllabic reduplication pattern may convey a progressive meaning. Hoeller (1932) describes reduplication in Guarayo as having the following values: "often, continuously, little by little, more and more, at intervals, here and there". These different meanings can be subsumed under the general function of "event-external repetition".

Up to now, we have argued that the dichotomy between monosyllabic and disyllabic reduplication patterns must be described in a less simplistic way than successive $V S$ iterative meaning and should also take into account the type of situations denoted by the verbs and the types of participants. This may be done by using the larger opposition "event-internal" $V S$ "event- 
external" plurality. Nevertheless, the dichotomy commonly presented for Tupi-Guarani languages is not so clearly cut in many languages of the family, including Emerillon.

1.4. Some cases of disyllabic reduplication expressing event-internal plurality

A good number of examples with disyllabic reduplication exemplify the "event-internal" repetition meaning, which is therefore not restricted to monosyllabic reduplication.

Just as with monosyllabic reduplication, the meaning of internalrepetition can be due to the plurality of participants (subjects or objects) as in (9) or to the notion of a distributed result as in (10). In both cases, it seems that the denoted situation is an activity. In (9), the reduplicated form of ojika "kill" denotes the traditional activity of killing fish that have been poisoned with the toxic juice of a creeper.

$$
\begin{aligned}
& \text { mun-a-kom o-[dika]djika- } \eta \text {. } \\
& \text { people-a-PL 3-RED-kill-PL } \\
& \text { 'People were killing them.' } \\
& \text { wã̃ũ-enam wila-we o-[eta]eta. Emerillon } \\
& \text { woman-TOP.SW wood-also 3-RED-cut }
\end{aligned}
$$

Descriptions of other Tupi-Guarani languages suggest that they also display bisyllabic reduplication with an internal-repetition meaning. Some Chiriguano examples given by Schuchard (1979) suggest an intensive meaning:

$$
\begin{aligned}
& \text { e-i-[nupã]-nupã. } \\
& \text { 1SG.IMP-3-RED-hit } \\
& \text { "“Hit him hard!", }
\end{aligned}
$$$$
\text { Chiriguano }
$$

Grenand (1980) proposes another meaning for Wayampi: a weakened meaning.

(12) a- $a-\underline{s u ? u}$

'I bite'

Wayampi, Grenand 1980

my segmentation 
Reduplication in Tupi-Guarani languages

b- $a-[s u ? u] s \underline{s u}$

'I chew'

\subsection{Summary}

In this semantic section, two facts have been underlined:

- First, the dichotomy between monosyllabic and disyllabic reduplication must be described in a less simplistic way than successive versus iterative meaning, and should also take into account the type of situations denoted by the different forms of the verb and the different types of participants. This can be done by using the larger opposition "eventinternal" versus "event-external" plurality.

- Second, in reality, the elegant semantic dichotomy is not easily applicable to the Emerillon data, since "event-internal" plurality may also be expressed by disyllabic reduplication. This is true for many other TupiGuarani languages and will be explained in the diachronic section of this paper.

But before this, we must examine the main difference in reduplication between Emerillon and other Tupi-Guarani languages, which concerns the phonological patterns involved in reduplication.

\section{Phonological description}

\subsection{Reduplication patterns}

We now turn to a description of reduplication as a phonological operation. Examples from all Tupi-Guarani languages suggest that the reduplicant copies the base according to a mono or disyllabic template. Only one copy is made, and no other modification alters the stem.
(13) a- a-i-mokón
Tupinamba, Jensen 1990
1SG-3-swallow
my segmentation
'I swallowed it.'
b- a-i-mo[kó]kón
'I swallowed them one after the other.' 
Françoise Rose

c- a-i-[mokó]mokón

'I swallowed them frequently.'

Canonical forms of Tupi-Guarani morphemes consist of one or two syllables (rarely more), each vowel being a syllable nucleus. Closed syllables (with a coda consonant) are restricted to the final position in the morpheme. This final coda consonant is excluded by the reduplication process.

(14) a- -pyhyk

'take, hold'

Kamaiura, Seki 2000

my segmentation

b- -pyhy-pyhyk

'take several times'

A morphophonological explanation could be put forward: at a morpheme boundary, one consonant preceding another tends to be deleted. In other words, if two identical strings follow each other, the final consonant of the first string must be dropped in front of the initial consonant of the second. But the following example shows that this hypothesis is irrelevant: the elision of the consonant appears also in front of a vowel.

$$
\begin{aligned}
& \text { a- } \frac{o-? a l}{3 \text {-fall }} \\
& \text { 'He falls' } \\
& \text { b- * [o?al }] \underline{o-P a l} \\
& \text { c- [o?a]o?al }
\end{aligned}
$$

Emerillon

We suggest that the absence of final consonant in the reduplicant may be explained in terms of moras: the reduplication process in Tupi-Guarani languages creates reduplicants consisting only of monomoraic syllables. The final consonant is thus systematically excluded from the copy.

Reduplication operates on a base consisting of the verbal stem or part of it, excluding suffixes (TAM, number) or clitics ("particles").

$$
\text { [ora]o-?al-oy }
$$

Emerillon

RED-3-fall-PL

'They fall one after the other.' 
A logical problem is raised by disyllabic reduplication on monosyllabical stems. Tupi-Guarani languages, including Emerillon, all seem to solve the problem the same way: to fill the disyllabic reduplicant template, they extend the base by including the preceding syllable, which is the last or single syllable of either a person marker, or a voice prefix. (Verbs are usually preceded by a person prefix in these languages.)

a- ere-syk

2SG-arrive

'You arrive.'

b- e[resy]re-syk

'You frequently arrive.'

(18)
Tupinamba, Rodrigues 1953

my segmentation

$$
\begin{array}{ll}
\text { a-lo-wag } & \text { pol } \\
\text { 1SG-CAUS.COM-go } & \text { pot } \\
\text { 'I moved the pot.' } &
\end{array}
$$

b- a-[lowa]lo-wag pol

'I moved the pot several times.'

Thus the phonological string of the copy does not correspond to a unique morphological unit.

In summary, reduplication in Tupi-Guarani languages involves different domains, defined on morphological and phonological criteria:

- either one syllable of the verbal stem (all of it, if it is monosyllabic), any possible coda consonant being excluded

- two syllables of the verbal stem (all of it, if it is disyllabic), any possible coda consonant being excluded

- one syllable of the verbal stem plus the last syllable of the preceding morpheme (with monosyllabic stems only), once again any possible coda consonant being excluded

The interesting fact is that these domains do not include the same syllables of the stem in Emerillon and in other Tupi-Guarani languages. Let us now illustrate the two patterns (monosyllabic and disyllabic) for both Tupi-Guarani in general and Emerillon in particular. 


\subsection{Monosyllabic reduplication}

The first reduplication template is monosyllabic, one could also say in that case monomoraic, the last consonant being deleted.

\subsubsection{In most Tupi-Guarani languages}

For the languages I know of, the monosyllabic pattern reduplicates the final syllable in Wayampi, Tupinamba, Guarayo, Anambé and Kamaiura.

(19) a- o-sala

Wayampi, Grenand 1989

'he breaks'

my segmentation

b- o-sa[la]la

'he splits'

(20) a- a-piso

'I pull out a feather'

Wayampi, Grenand 1980

my segmentation

b- a-pi[ $[s o] \underline{s o}$

'I am plucking a fowl'

\subsubsection{In Emerillon}

On the contrary, monosyllabic reduplication in Emerillon copies the first syllable of the stem. Several examples with plurisyllabic (all disyllabic) stems show this clearly:

"fre, wane

brother incessantly DEM 3-RED-fart

Emerillon

"'Brother, this one keeps on farting""

\subsection{Disyllabic reduplication}

The second reduplication pattern is disyllabic, with monomoraic syllables, the coda consonant being excluded. 


\subsubsection{In most Tupi-Guarani languages}

In parallel to the monosyllabic pattern, the disyllabic pattern reduplicates the last two syllables in Wayampi, Tupinamba, Anambé, Chiriguano, Guarayo and Kamaiura.
(22) a- o-j-apisi
3-REFL-fight
'They fight.'
Wayampi, Ganozzi, p.c. my segmentation
b- o-j-a[pisi]pisi
3-REFL-RED-fight
'They (kids) quarrel.'
(23) a- $a[i k \tilde{a}]$
'to trim'
Anambé, Julião, p.c. my segmentation
b- a[ikã $] \underline{i k \tilde{a}}$
'to trim several times'

\subsubsection{In Emérillon}

The Emerillon disyllabic pattern involves two syllables of the verbal stems. All examples being with monosyllabic or disyllabic stems, it is actually impossible to decide if they are the initial or final syllables of the stems.

$$
\begin{array}{ll}
\text { a-[inu ]inuy zebira } & \text { Emérillon } \\
\text { 1SG-RED-put music } & \\
\text { 'I am always listening to music.' } &
\end{array}
$$

\subsection{Discussion}

The oddity of the different anchorage of reduplication within the TupiGuarani family seems difficult to explain. Moreover, Emerillon functions differently from the languages of the same subgroup $\left(8^{\text {th }}\right.$ subgroup, in Rodrigues 1984-85) presented in this paper: Wayampi and Anambé.

Reduplication patterns involve the same kind of canonical forms in all Tupi-Guarani languages, but they copy different parts of the stem. 
Nevertheless, with disyllabic reduplication on disyllabic stems, the forms resulting from the two different models of reduplication do not differ (25).

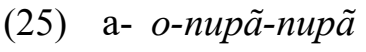
Wayampi, Jensen 1990 3-hit-RED Jensen's segmentation

'He clubbed it (a fish) repeatedly.'

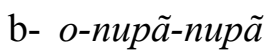

Emerillon

3-RED-hit

'He hit it several times.'

A further discussion to be considered at this point is how to tell apart the reduplicant from the base. We assumed in this paper that the reduplicant was placed before the base. An alternative analysis is more widespread: the reduplicant would copy one or two full syllables (including the coda consonant) and follow the base, which would itself lose its coda consonant (Rodrigues 1953 for Tupinamba, Jensen 1993 for Wayampi \& 1998 for Tupi-Guarani in general, Everett and Seki 1985). b- is an example the way Jensen presents it:

(26) a- a-i-mokón

Tupinamba, Jensen 1990

1SG-3-swallow

'I swallowed it.'

b- *o-i-mokó-kón

3A-3P-swallow-REDUP

Proto-Tupi-Guarani, Jensen 1998

Jensen's segmentation

'He swallowed them one after the other.'

In this paper, I argue that this description is needlessly complicated: why would the coda consonant be deleted from the base, while it is saved in the copy? The description gives no explanation for this (remember we saw with (15) that it could not be a morphophonological rule). Everett and Seki (1985) still argue for a morphophonological rule. They consider, for Kamaiura only, than the reduplicative morpheme is expressed as a /CVCVC/ suffix. When the phonemic melody is too short to fill the initial $\mathrm{C}$ slot of the suffix template, the consonant deletion rule is still triggered by the empty consonant. We have then to accept that the deletion rule operates at the prosodic template level, rather than on a phonemic melody. 
My preference goes for a more economical analysis, using a reduplicant template based on prosody: if each reduplicated syllable must be monomoraic, then the coda consonant is logically absent from the copy, but still present in the base. Consequently, we assume that the copy precedes the base.

We understand that the kind of description illustrated in (26) -suffixation rather than prefixation- was motivated by the wish to maintain correspondence between the phonological and morphological boundaries. Here is one of Rodrigues' examples, with his own segmentation:

$$
\begin{aligned}
& \text { a- ere-syk } \\
& \text { 2SG-arrive }
\end{aligned}
$$

Tupinamba, Rodrigues 1953

'You arrive.'

$$
\text { b- ere-sy-re-syk }
$$

'You frequently arrive.'

The segmentation tries to preserve entire morphemes. Nevertheless, the reand $s y$-parts do not correspond to a whole morpheme. In their article, Everett and Seki (1985) reject Bruce Hayes's account of Kamaiura reduplication as the infixation of a -CVCV- skeleton before the penultimate syllable of the stem, underlining the fact that there is no infixation in Tupi-Guarani. As a counter-argument, note that if we adopt their analysis of suffixation for the Emerillon data, once again reduplication will look like "infixing", or rather like internal reduplication. The copy, if it follows the base, shows up within the stem (28b).

(28) prefixation (our analysis of Emerillon):

a- $o-[s u] \underline{s u}$ ? $u$

suffixation (following Everett \& Seki analysis of Kamaiura) :

b- o-su[su]?u

Since the data make it necessary to dissociate phonological and morphological segmentation, we will prefer the simpler hypothesis concerning Copy-Base order: the copy precedes the base, and the absence of the coda consonant in the copy is explained by its canonical form consisting of only monomoraic syllables. Thus the segmentation of (26) and (27) is for us:

(29) a- a-i-mokón

1SG-3-swallow

Tupinamba, Jensen 1990

'I swallowed it.' my segmentation 
b- a-i-mo[kó]kón

'I swallowed them one after the other.'

(30) a- ere-syk

Tupinamba

2SG-arrive

'You arrive.'

my segmentation

b- e[resy]re-syk

'You frequently arrive.'

The copy is placed just before the base, therefore inserted within the lexeme in (29) and within the person marker in (30). This case just reminds us that morphological processes are not limited to juxtaposition of morphemes. In Optimality Theory, it could be nicely explained in terms of competition between constraints. The markedness constraint -requiring only monomoraic syllables in the copy- is higher in the hierarchy than the faithfulness constraint -requiring correspondence between output and lexical input (see for example Kager 1999).

The different analysis of the order Base/Copy does not nevertheless solve the problem of the unusual anchorage of Emerillon reduplication within the Tupi-Guarani family.

\section{Diachrony}

In the preceding sections, it has been established that Emerillon does not follow the semantic and phonological models of reduplication of other Tupi-Guarani languages. This difference may partly be explained by diachronic or areal phenomena.

Note first that descriptions do not explicitly claim to give "reconstructions" for Tupi-Guarani languages, but rather use Rodrigues' description of Tupinamba reduplication as a basis and extend it to other languages. 


\subsection{Diachronic information explaining the semantics of Emérillon reduplication patterns}

Diachronic information helps us understand the blurred semantics of Emerillon reduplications. The most interesting evolution, often left out, is that monosyllabic reduplication as a productive phenomenon has in fact disappeared from many Tupi-Guarani languages. These languages retain frozen forms, like mokõ-kõ ('swallow one after the other') in Wayampi, but do not have monosyllabic reduplication as a productive phenomenon. In such languages, disyllabic reduplication takes on the two meanings, e.g. in Wayampi.

In Emerillon, occurrences of monosyllabic reduplication are clearly less numerous than those of disyllabic reduplication. The semantics of monosyllabic reduplication is more homogenous than that of disyllabic reduplication. One hypothesis is that monosyllabic reduplication in Emerillon is beginning to decline, and disyllabic reduplication takes on the meaning of "event-internal plurality" as a possibility.

3.2. Diachronic or areal information about the Emerillon phonological patterns of reduplication

Concerning the phonological pattern, no clear explanation emerges from diachrony. Three points are however worth mentioning:

Interesting is Jensen's assertion that monosyllabic reduplication repeats the last stressed syllable of the word, and disyllabic reduplication the last stressed syllable and the one preceding it (Jensen 1989, p. 119-21). However, if stress in Proto-Tupi-Guarani is reconstructed on the final syllable of the stem, it occurs on the penultimate syllable in several languages like Chiriguano and Wayampi. In those languages, reduplication still involves the last syllable or the last two syllables. Position of stress does not seem to constitute a good explanation for the different models of reduplication between Emérillon (where stress seems to occur either on the final or on the penultimate syllable of the stem) and the other Tupi-Guarani languages.

Second, in Xipaya, a Tupi language of the Juruna family, initial reduplication is well attested (Rodrigues C., p.c.). Xipaya's reduplication involves both ends of the verb stem. In the "real" mode, the initial syllables are copied, while in the "unreal" mode, the last syllables of the verb are 
copied. Therefore, Emerillon is not the only Tupi language with initial reduplication; unfortunately, we do not know the extent of this phenomenon in the Tupi family.

Finally, in Arawak, another large Amazonian family, initial and final reduplication coexist, sometimes in the same languages. (Aikhenvald 1996)

If this does not tell us why Emerillon displays an initial reduplication, at least it shows that Emerillon is not such an oddity in the region.

\section{Abbreviations}

$\begin{array}{ll}\text { 1EX } & \text { first person exclusive } \\ \text { 2SG.IMP } & \text { second person of the imperative } \\ \text { ABL } & \text { ablative postposition } \\ \text { CAUS.COM } & \text { causative-comitative } \\ \text { CONTRAST } & \text { contrastive } \\ \text { DEM } & \text { demonstrative } \\ \text { INTENS } & \text { intensive } \\ \text { PL } & \text { plural } \\ \text { RED } & \text { reduplicant } \\ \text { REFL } & \text { reflexive } \\ \text { TOP.SW } & \text { topic switch }\end{array}$

\section{Notes}

1. I am grateful to Denis Creissels for his comments and support.

2. Concerning these last two languages, I wish to thank Wolf Dietrich for sharing the information. Thanks also to Risoleta Julião for Anambé's data.

3. Transcriptions follow the IPA conventions, except those of Tupinambá and Kamaiurá where " $y$ " stands for " $i$ ". The accent on a vowel indicates stress. Underlined strings correspond to the base of reduplication, and brackets mark the reduplicant. The analysis of strings as base and reduplicant is ours, except in part 2.4 where this point is discussed.

4. My translation for "desintegración objetual".

5. My translation for "une action qui se prolonge, qui dure, tout en se répétant".

6. My translation.

7. The only four possible patterns are V.V, V.CV, CV.V, CV.CV.

8. Information on Urubu (also from the $8^{\text {th }}$ subgroup) is limited to examples in Kakumasu's work. His examples are all monosyllabic reduplication on 
monosyllabic stems, or disyllabic reduplication on disyllabic stems, which does not inform us on the initial/final reduplication discussion.

9. Infixation is to be understood in terms of affixation of a bound morpheme within a stem.

\section{References}

Aikhenvald A. Y.

1996 Amazonian languages, The Third Australian Linguistic Institute, Australian National University.

Cusic D.

1981 Verbal plurality and aspect. PhD diss., Stanford University.

cited in "Reduplication and infixation in Yurok: morphology, semantics and diachrony", Garrett A., 2001, IJAL, Vol. 67, n 3.

Everett D. L. and Seki L.

1985 Reduplication and CV Skeleta in Kamaiurá. Linguistic Inquiry 16 (2), 326-330.

García-Medall J.

2000 Sóbre reduplicación morfológica en lenguas amerindias. In I Simposio Antonio Tovar sobre Lenguas Amerindias, E. Ridruejo and M. Fuertes (eds.). Valladolid: Tordesillas.

Grenand F.

1980 La langue wayãpi (Guyane française). Phonologie et grammaire. (Langues et civilisations à tradition orale 41.) Paris: SELAF.

Grenand F.

1989 Dictionnaire wayãpi-français. Paris: Peeters / SELAF.

Hoeller A.

1932 Grammatik der Guarayo-Sprache. Hall (Tirol).

Jensen C.

1989 O desenvolvimento histórico da língua Wayampi. Campinas: Editora da Unicamp.

Jensen C.

1990 Cross-referencing changes in some Tupí-Guaraní languages. In Amazonian Linguistics, Studies in Lowland South American Languages, D. Payne, 117-158. Austin: University of Texas Press.

Jensen C.

1998 Comparative Tupí-Guaraní Morpho-syntax. In Handbook of Amazonian languages, D. C. Derbyshire and G. K. Pullum, Vol. IV, 490-603. Berlin: Mouton de Gruyter.

Kager R. 
Françoise Rose

1999 Correspondance in reduplication. In Optimality Theory, R. Kager. Cambridge: Cambridge University Press.

Kakumasu J.

1984 Urubu-Kaapor. In Handbook of Amazonian languages, D. C. Derbyshire and G. K. Pullum, Vol. I, 326-403. Berlin: Mouton de Gruyter.

Rodrigues A. D.

1953 Morfologia do verbo Tupi. Letras, Separata $\mathrm{n}^{\circ} 1,121-152$, Curitiba.

Rodrigues A. D.

1984-1985 Relações internas na família linguïstica Tupí-Guaraní. Revista de Antropologia 27-28, 33-53.

Rose F.

2000 Eléments de phonétique, phonologie et morphophonologie de l'émérillon (Teko). Master Thesis, Université Lyon 2.

Schuchard B.

1979 Nane ñë. Gramática guaraní para castellanohablantes. Santa Cruz de la Sierra.

Seki L.

2000 Gramática do Kamaiurá. Campinas: Editora da Unicamp.

Vendler Z.

1967 Linguistics and Philosophy. Ithaca: Cornell University Press. 